\title{
PERTIMBANGAN PUTUSAN HAKIM DALAM PENJATUHAN PIDANA \\ PENJARA TERHADAP ANAK YANG MELAKUKAN TINDAK PIDANA \\ PEMBUNUHAN
}

\author{
ERISMIARTI \\ erismiarti7@gmail.com \\ 1910095600052 \\ SEKOLAH TINGGI ILMU HUKUM PADANG
}

\section{A. Latar Belakang}

Anak adalah bagian yang tidak terpisahkan dari keberlangsungan hidup manusia juga keberlangsungan suatu bangsa dan Negara. Agar kelak mampu bertanggung jawab dalam keberlangsungan bangsa dan Negara, setiap anak perlu mendapat perlindungan dan kesempatan yang seluas-luasnya untuk tumbuh dan berkembang secara optimal baik fisik, mental, maupun sosial. Untuk itu, perlu dilakukan upaya perlindungan untuk mewujudkan kesejahteraan anak dengan memberikan jaminan terhadap pemenuhan hak- haknya tanpa ada tindakan atau perlakuan diskriminatif. Pada hakikatnya anak tidak dapat melindungi diri sendiri dari berbagai macam tindakan yang dapat menimbulkan kerugian dalam berbagai bidang kehidupan dan penghidupan. Anak perlu mendapat perlindungan dari kesalahan penerapan peraturan perundang-undangan yang diberlakukan terhadap dirinya, yang dapat menimbulkan kerugian mental, fisik, maupun sosial. Perlindungan anak dalam hal ini disebut perlindungan hukum/yuridis (legal protection).

Peraturan perundang - undangan yang telah dibuat oleh pemerintah Indonesia untuk memberikan perlindungan hak terhadap anak, antara lain : Undang - Undang No.4 Tahun 1979 tentang Kesejahteraan anak, Undang-Undang Nomor 39 Tahun 
1999 tentang Hak Asasi Manusia, Undang-Undang nomor 3 tahun 1997 tentang Pengadilan Anak, Undang - Undang nomor 23 tahun 2002 tentang Perlindungan Anak yang secara keseluruhan mengemukakan, anak adalah seseorang yang belum berusia 18 (delapan belas) tahun termasuk anak yang masih di dalam kandungan, UndangUndang Nomor 11 Tahun 2012 tentang Sistem Peradilan Pidana Anak dimana secara substansinya Undang-Undang tersebut mengatur hak-hak anak yang berupa, hak hidup, hak atas nama, hak pendidikan, hak kesehatan dasar, hak untuk beribadah menurut agamanya, hak berekspresi, hak untuk berpikir, hak untuk bermain, hak untuk berkreasi, hak untuk beristirahat, hak untuk bergaul dan hak jaminan sosial.

Anak dengan latar belakang ketidak harmonisan keluarga, tentu akan lebih berpotensi untuk mencari sendiri lingkungan di luar keluarga yang bisa menerima apa adanya. Apabila lingkungan tersebut membawa efek positif tentu akan menyelesaikan masalah si anak dan membawa anak tersebut kearah hal yang bersifat positif juga. Sebaliknya, jika lingkunagn negatif yang didapat, inilah yang justru akan menjerumuskan anak untuk melakukan hal - hal yang kearah negatif,termasuk mulai melakukan pelanggaran hukum, seperti mencuri, mencopet, memperkosa, bahkan bisa membunuh. Apabila pendidikan keluarga gagal, maka anak cenderung melakukan tindakan kenakalan dalam masyarakat dan tidak jarang menjurus kearah tindakan kejahatan atau kriminal.

Gejala kenakalan anak akan terungkap apabila kita meneliti bagaimana ciri ciri khas atau ciri umum yang menonjol pada tingkah laku dari anak - anak puber, antara lain :

1. Rasa harga diri yang semakin menguat dan gengsi yang terlalu besar, serta kebutuhan untuk memamerkan diri, sementara lingkungan masyarakat dewasa ini sedang demam materiil di mana orang mendewa - dewakan kehidupan atau 
kemewahan (luxury), sehingga anak - anak muda adalah usia yang emosi dan mentalnya belum matang serta dalam situasi labil, maka dengan mudah ia ikut terjangkit nafsu serakah dunia materiil. Apabila anak tidak mampu mengendalikan emosi - emosi yang semakin menekan, kemudian pengawasan dan pendidikan dari orang tua kurang, maka akan mudah sekali anak muda/remaja yang terjerumus dengan melakukan tindakan kriminal, misalnya mencuri, menodong, dan menggarong demi mendapatkan penghasilan tanpa harus mengeluarkan banyak tenaga dan cucuran keringat.

2. Energi yang berlimpah - limpah memanifestasikan diri dalam bentuk keberanian yang condong melebih - lebihkan kemampuan diri sendiri, misalnya kesukaan anak muda untuk kebut - kebutan di jalan raya, serta cepat emosi dalam bergaul mengakibatkan perkelahian yang dapat menimbulkan luka parah serta dapat menyebabkan kematian.

3. Senang mencari perhatian dengan jalan menonjolkan diri, misalnya dengan jalan mabuk - mabukan dengan minuman keras.

Hal - hal tersebut diatas bisa dimengerti fase - fase remaja dan adolescent adalah suatu proses transisi di mana tingkah laku anti sosial yang potensial disertai banyak pergolakan hati dan kekisruhan hati membuat anak remaja /adolescent kehilangan control, kendali emosi yang meletup menjadi boomerang baginya. Apabila dibiarkan tanpa adanya pembinaan dan pengawasan yang tepat, cepat, serta terpadu oleh semua pihak, maka gejala kenakalan ini akan menjadi tindakan - tindakan yang mengarah kepada tindakan yang bersifat kriminalitas. Dalam pembahasannya ada kelompok yang menekankan segi pelanggaran hukumnya ada pula kelompok yang menekanka pada sifat tindakan anak apakah sudah menyimpang dari norma yang berlaku atau belum melanggar hukum. Namun semua sepakat bahwa dasar pengertian 
kenakalan anak adalah perbuatan atau tingkah laku bersifat anti sosial. Ditinjau dari segi sosiologi, menurut H. Sutherland menyelidiki bahwa kejahatan merupakan suatu persoalan yang paling serius atau penting yang bersumber di masyarakat, masyarakat yang memberikesempatan untuk melakukan kejahatan dan masyarakat sendiri yang menanggung akibat dari kejahatan tersebut walaupun secara tidak langsung.

Oleh karena itu untuk mencari sebab - sebab kejahatan atau sifat jahat itu sendiri bukan karena pewarisan, tetapi karena di pelajari dalam pergaulan di masyarakat, sedangkan pergaulan di masyarakat itu adalah berbeda - beda, yang sangat di pengaruhi oleh keadaan lingkungan sendiri. Problematika hukum yang belakangan ini sering muncul di kalangan masyarakat adalah tindak pidana yang pelakunya bukan orang dewasa saja, melainkan anak yang usianya dibawah 18 (delapan belas) tahun menurut Undang - Undang No. 23 tahun 2002 tentang Perlindungan anak, membuat penulis merasa perlu dan tertarik untuk mengadakan penelitian mengenai masalah tindak pidana anak, dan mengambil judul

“Pertimbangan Putusan Hakim dalam Penjatuhan Pidana Penjara terhadap Anak yang melakukan Tindak Pidana Pembunuhan.”

\section{B. Rumusan Masalah}

1. Apakah pertimbangan Hakim dalam penjatuhan putusan pidana penjara terhadap anak yang melakukan tindak pidana pembunuhan?

\section{Tujuan Penelitian}

Berkaitan dengan permasalahan tersebut diatas maka tujuan penelitian untuk menyusun proposal ini adalah : 
1. Untuk mendapatkan data apa yang menjadi dasar Pertimbangan Hakim dalam Penjatuhan Pidana Penjara terhadap Anak yang melakukan Tindak Pidana Pembunuhan.

2. Untuk mendapatkan data bagaimana penerapan unsur - unsur dari Pasal 338 Kitab Undang - Undang Hukum Pidana mengenai tindak pidana pembunuhan yang dilakukan oleh anak.

\section{Kegunaan Penelitian}

1. Hasil penelitian ini diharapkan dapat bermanfaat bagi pengembangan ilmu hukum, khususnya untuk memperluas pengetahuan dan menambah referensi khususnya mengenai hal-hal yang berkaitan dengan penjatuhan pidana penjara bagi anak yang melakukan tindak pidana pembunuhan.

2. Dapat memberikan sumbangan pemikiran bagi aparat penegak hukum khususnya pada hakim dalam penjatuhan pidana penjara terhadap anak yang melakukan tindak pidana pembunuhan secara professional, manusiawi dan menjunjung tinggi keadilan.

\section{E. Metode Penelitian}

\section{Jenis Penelitian}

Dalam melakukan penelitian hukum ini, jenis penelitian yang digunakan adalah penelitian hukum normatif, yaitu suatu penelitian yang berfokus pada norma dan penelitian ini memerlukan data sekunder (bahan hukum) sebagai data utama. Penelitian hukum normatif dapat berupa inventarisasi hukum positif, usaha-usaha penemuan asas-asas dasar falsafah (doktrin) hukum positif, usaha penemuan hukum (in concreto) yang sesuai untuk diterapkan guna penyelesaian perkara tertentu. 
Penelitian hukum normatif memerlukan lima tugas, yaitu deskripsi hukum positif, sistemasi hukum positif, analisis hukum positif, interprestasi hukum positif, dan menilai hukum positif.

2. Sumber Data

Dalam penelitian hukum normatif ini sumber data yang digunakan adalah data sekunder. Data sekunder terdiri dari :

a. Bahan hukum primer

Meliputi peraturan perUndang - Undangan yang terkait dengan penulisan ini, yakni :

1) UUD 1945

2) Kitab Undang - Undang Hukum Pidana (KUHP)

3) Undang - Undang No. 11 tahun 2012 tentang system Peradilan Pidana Anak

4) Undang - Undang No.23 tahun 2002 tentang Perlindungan Anak

5) Undang - Undang No. 4 tahun 1979 tentang Kesejahteraan Anak

6) Undang - Undang No. 39 tahun 1999 tentang Hak Asasi Manusia

7) Undang - Undang No. 3 tahun 1997 tentang Pengadilan Anak

8) Putusan Hakim yang berkaitan dengan penjatuhan pidana bagi anak yang melakukan tindak pidana.

b. Bahan Hukum Sekunder

Bahan hukum sekunder berupa pendapat hukum dan pendapat non hukum yang diperoleh dari buku - buku, internet (website), dan prektisi hukum, seperti :

1) Buku - buku dan tulisan ilmiah yang berhubungan dengan hukum pidana.

2) Buku - buku dan tulisan ilmiah yang berhubungan dengan putusan hakim.

3) Buku - buku dan tulisan ilmiah yang berhubungan dengan tindak pidana. 
4) Buku - buku dan tulisan ilmiah yang berhubungan dengan anak sebagai pelaku tindak pidana.

5) Internet

c. Bahan Hukum Tersier

Bahan hukum yang memberikan penjelasan terhadap bahan hukum primer dan bahan bukum sekunder, yaitu :

1) Kamus Hukum dengan penerbit Citra Umbara Bandung

2) Kamus Besar Bahasa Indonesia karangan tim penyusun Kamus Pusat Pembinaan dan Pengembangan Bahasa depatrtmen Pendidikan dan Kebudayaan Republik Indonesia.

3. Cara Pengumpulan Data

1) Studi Kepustakaan

Studi kepustakaan dilaukan dengan cara membaca dan mempelajari pendapat hukum dan pendapat non hukum yang diperoleh dari buku - buku, Kamus Besar Bahasa Indonesia, dan internet (website) yang berhubungan dengan " apakah pertimbangan putusan hakim berupa penjatuhan pidana penjara terhadap anak yang melakukan tindak pidana pembunuhan “ pada setiap proses pemeriksaan perkara pidana di Pengadilan Negeri Sleman.

2) Wawancara

Wawancara yaitu pengumpulan data dengan cara bertanya langsung kepada narasumber. Narasumber adalah subyek/seseorang yang berkapasitas sebagai ahli, professional atau pejabat yang memberikan jawaban atas pertanyaan peneliti berdasarkan pedoman wawancara yang berupa pendapat hukum terkait dengan rumusan masalah hukum yang diteliti. Wawancara yang digunakan adalah wawancara bebas terpimpin, yaitu menggunakan daftar pertanyaan sebagai pedoman dan 
memungkinkan timbulnya pertanyaan lain yang berkaitan dengan “ apakah pertimbangan putusan hakim dalam penjatuhan putusan hakim berupa penjatuhan pidana penjara terhadap anak yang melakukan tindak pidana pembunuhan " pada setiap proses pemeriksaan perkara di Pengadilan Negeri Sleman.

\section{Metode Analisis}

Adapun bahan hukum yang diperoleh dalam penelitian studi kepustakaan, aturan perundang - undangan, dan artikel dimaksud penulis uraikan dan hubungkan sedemikian rupa, sehingga disajikan dalam penulisan yang lebih sistematis guna menjawab permasalahan yang telah dirumuskan. Bahwa carapengolahan bahan hukum dilakukan secara deduktif yakni menarik kesimpulan dari suatu permasalahan yang bersifat umum terhadap permasalahan konkret yang dihadapi. Selanjutnya bahan hukum yang ada dianalisis untuk mengetahui penerapan sanksi pidana terhadap anak yang melakukan tindak pidana sehingga sesuai dengan ketentuan yang berlaku. Permasalahan yang akan diteliti dalam penulisan ini terkait dengan penjatuhan pidana terhadap anak yng melakukan tindak pidana. Dalam melaksanakan penelitian ini mengambil beberapa putusan hakim terkait dengan pidana yang dijatuhkan oleh hakim terhadap anak yang melakukan tindak pidana, sehingga yang menjadi dasar pertimbangan hakim dalam penjatuhan putusan terhadap anak yang melakukan tindak pidana dapat ditarik kesimpulan yang merupakan hasil penelitian ini.

\section{F. Orisinalitas Penelitian}

Penelitian mengenai pertimbangan putusan hakim dalam memutus perkara tindak pidana pembunuhan yang dilakukan oleh anak merupakan hasil karya asli penulis bukan duplikasi. Beberapa skripsi yang bertema sama, antara lain : 
1. Iqbal Aji Ramdani, Ilmu Hukum, Universitas Muhammadiyah Mataram, Mataram. NPM : 616110029, judul : Sanksi Pidana Terhadap Pelaku Pembunuhan Yang Dilakukan Oleh Anak Dibawah Umur Menurut Hukum Pidana Anak Di Indonesia. Adapun rumusan masalahnya adalah Bagaimana penerapan sanksi pidana terhadap pelaku pembunuhan yang dilakukan oleh anak di bawah umur berdasarkan Undang-Undang Nomor 11 Tahun 2012 tentang Sistem Peradilan Pidana Anak? Dan Bagaimana pertimbangan hakim dalam menjatuhkan sanksi pidana terhadap pelaku pembunuhan yang dilakukan oleh anak di bawah umur dalam putusan hakim Nomor 12/Pid.Sus Anak/2016/PN.Mtr? Tujuan penelitian adalah untuk mengetahui penerapan sanksi pidana terhadap pelaku pembunuhan yang dilakukan oleh anak di bawah umur berdasarkan Undang-Undang Nomor 11 Tahun 2012 Tentang Sistem Peradilan Pidana Anak. Hasil penelitian menunjukan bahwa ketentuan-ketentuan yang dijadikan sebagai dasar penerapan sanksi pidana terhadap anak tercantum dalam Undang-Undang Republik Indonesia Nomor 11 Tahun 2012 meliputi pembatasan umur anak, penjatuhan sanksi dan hak-hak anak, sedangkan penerapan sanksi yang digunakan berupa sanksi pidana dan sanksi tindakan. Pertimbangan yang diambil hakim pada putusan secara objektif memperhatikan bahwa usia anak masih di bawah umur dan mempertimbangkan hak-hak anak sesuai dengan UndangUndang Nomor 11 Tahun 2012 tentang Sistem Pengadilan Pidana Anak guna memenuhi rasa keadilan anak sebagai pelaku tindak pidana maupun rasa keadilan masyarakat pada umumnya.

2. Lilik Siyaga, Ilmu Hukum, Universitas Jenderal Soedirman, Purwokerto. NPM : E1E008039, judul : Tindak Pidana terhadap nyawa manusia yang dilakukan oleh anak. Adapun rumusan masalahnya adalah bagaimana penerapan pasal 338 
KUHP pada tindak pidana terhadap nyawa manusia yang dilakukan oleh anak? Tujuan penelitian adalah untuk mengetahui dan mencari data bagaimana penerapan pasal 338 KUHP pada tindak pidana terhadap nyawa manusia yang dilakukan oleh anak. Hasil penelitian yang pertama adalah penelitian kepustakaan, penelitian ini dilakukan untuk memperoleh data sekunder, yaitu bahan - bahan hukum primer, bahan - bahan hukum sekunder dan bahan - bahan hukum tersier. Hasil penelitian kedua, dilakukan penelitian lapangan. Untuk menunjang data sekunder yang diperoleh daripenelitian kepustakaan, maka dilakukan penelitian lapangan yang berfungsi sebagai mengambil data lapangan yang berada dalam instansi - instansi yang terkait. Sebelum penelitian ini dilakukan, yang harus disiapkan adalah mempersiapkan surat izin untuk memperoleh data yang relevan.

3. Hermanus I Made Ervan Adnyana Putra, Ilmu Hukum, Universitas Atmajaya Yogyakarta, NPM : 090510143, judul : Dasar pertimbangan Hakim dalam Penjatuhan Pidana terhadap Anak yang melakukan Tindak Pidana. Adapun rumusan masalahnya, yaitu apakah yang menjadi faktor anak melakukan tindak pidana? Apa yang menjadi dasar pertimbangan hakim dalam penjatuhan pidana terhadap anak yang melakukan tindak pidana? Tujuan penelitian adalah untuk mendapatkan data mengenai faktor - faktor apa saja yang menyebabkan anak melakukan tindak pidana. Untuk mendapatkan data yang menjadi dasar pertimbangan hakim dalam penjatuhan pidana terhadap anak yang melakukan tindak pidana. Hasil penelitian adalah permasalahan yang akan diteliti dalam penulisan ini terkait dengan penjatuhan pidana terhadap anak yang melakukan tindak pidana. Dalam melaksanakan penelitian ini mengambil beberapa putusan hakim terkait dengan pidana yang dijatuhkan oleh hakim terhadap anak yang melakukan tindak pidana. Dari beberapa putusan hakim tersebut kemudian 
dianalisis bagaimana pertimbangan hakim dalam menjatuhkan putusan terhadap anak yang melakukan tindak pidana. Putusan yang menjadi bahan penelitian ini merupakan putusan hakim dari peradilan di tingkat yang berbeda, yaitu Pengadilan Negeri, Pengadilan Tinggi,dan mahkamah agung sehingga dapat ditarik kesamaan-kesamaan yang menjadi dasar pertimbangan hakim dalam penjatuhan putusan terhadap anak yang melakukan tindak pidana. Melalui kesamaan-kesamaan tersebut akhirnya dapat ditarik kesimpulan yang merupakan hasil penelitian ini.

\section{Daftar Pustaka}

Adami Chazawi, 2006, Kemahiran dan Keterampilan Praktik Hukum Pidana, cetakan pertama, Bayumedia Publishing, JawaTimur.

Simanjuntak, 2006, Kriminologi, cetakan pertama, Tarsito, Bandung

Bunadi Hidayat, 2009, Pemidanaan Anak dibawah Umur, PT.Alumni, Bandung.

GatotSupramono, 2005, Hukum Acara Pengadilan Anak, cetakan kedua, Djambatan, Jakarta.

Lilik Mulyadi, 2002, Hukum Acara Pidana, cetakan Pertama, PT. Citra Aditya Bhakti, Bandung.

M. Hasan Wadong, 2000, Advokasi Hukum Perlindungan Anak, Grasindo, Jakarta.

Wagiati Soetodjo, 2006, Hukum Pidana Anak, cetakan Pertama, Rafika Aditama, Bandung.

http://repository.ummat.ac.id/841/1/COVER-BAB\%20III.pdf 